\title{
The explosion in Preferential Trade Agreements (PTAs) With Improve efficiency and welfare on Member Countries.
}

\author{
${ }^{1}$ Audu, Anyesha Amos, ${ }^{2}$ Danjuma Naisla Hassan, ${ }^{3}$ Musa Oliver Zhebu \\ ${ }^{1}$ Nasarawa State Polytechnic, Department of Social Sciences, Business Management Unit, P M B 109, Lafia- \\ Nigeria. \\ ${ }^{2}$ Nasarawa State Polytechnic, Department of General Studies, P. M.B 109, Lafia-igeria. \\ ${ }^{3}$ Nasarawa State University, Registry Department,P.M.B 1022 Keffi-Nigeria
}

\begin{abstract}
The relevant of preferential trade agreement between diverse countries of the World can't be overemphasis, been a form of economic integration for equal member countries with non-discriminatory, sincerity to the terms of the agreement with essentiality in economic advancement, growth and poverty reduction between member countries who are involved in the trade. The PTAs examples includes EU, NAFTA ASEAN etc, more so, the trade exploded in the past years as the developed nations create large market as ASEAN, Mercosur etc. However, the result of trade creation to substitute high cost domestic production by low cost import from other countries, due to shift from less efficient to more efficient producer which increases country's welfare. While, on the other hand, trade diversion result to substitute of low cost imports from nonmember country with high cost imports from member country. However, the research conclude by explaining the good ground of efficiency and welfare gain by members countries which burst trade creation, improve income through easy imports from countries involved and enhances comparative advantage through market liberalization, border elimination and global economic integration by outburst of welfare and efficiency increase of member countries.
\end{abstract}

Keyword: Preferential trade Agreement, efficiency and welfare gain, trade creation, trade diversion.

\section{Introduction.}

Preferential Trade Agreements is the agreement that is made up of several countries with the objectives to gain opportunity for external market liberalization, though the challenge of trade liberalization and negotiation are among the reason for PTAs explosion over the years. While the benefit of PTAs come to includes long-term trade strap and border elimination [1]. In an attempt to accomplish this work, the explanation of key concepts and in-depth understanding of relevant areas as; trade creation and trade diversion, trade and welfare and empirical analysis to state whether trade increases welfare or not . While attempt to look at PTAs raise and outburst over the years through a coherent interpretation of economic integration which is equally essential and further explanations on in-depth welfare and efficiencies gains from PTAs are the concluding part of the work and the contribution of the paper.

\section{Preferential Trade Agreement.}

Preferential trade agreement is formal agreement between diverse countries to limit tariff for certain products. It's a form of economic integration for equal access for members' countries, non-discriminatory and sincerity to the preferential trading agreement with low barriers to trade, and can only be effective with the nations forming a common trade policy to lessen trade barriers and integration [2]. However, preferential trade agreement (PTA's) has been the core of regional trade integration in the World this enhanced economic advancement, growth and poverty reduction through the World trade [3]. However, more that PTA's countries gain access to external market liberalization, secure environment of trade and strategic market. The sudden increase in PTA's members countries over the years is swift growing, its policy and critical work goes beyond barriers such as boundary elimination, improved members' countries and agreement on issues of investment, trade facilitation, competition policy [1]. Though, specifics of each PTAs vary distinctly: More that trade is not the same, but all have generally one thing in common: a discriminatory tendency, against other countries which are non-members of trade agreements [4]. However PTAs examples includes: EU, NAFTA, ASEAN etc. On Free Trade Agreement each member-country retains its own tariff structure against non-country members, while, a custom union is free trade area with common external trade policies, which PTAs fasten to explode in both developed and developing nations in the past years. However, it can be inferred that developing countries have actively participate in the expansion of PTAs and use PTAs as means to create larger Market such as ASEAN, Mercosur etc [4]. 


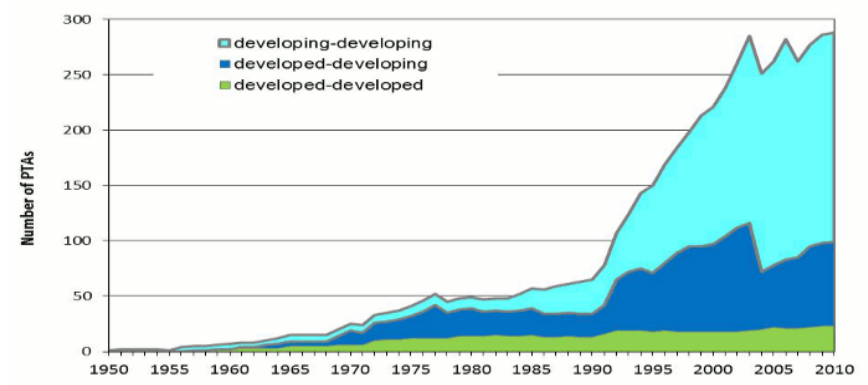

Nevertheless, PTAs continues to explode as in below Fig 1.

Source: WTO Secretariat, 2011.

However, [5] posit that PTAs has grown over the years with 70 countries in 1990 and increased to approximately 300 in 2010 demonstrate attribute of international policy, and encompass exemption to Most Favored Nation (MFN), situation of WTO (non-discriminatory tariff) which all WTO countries fit in to at least one PTAs and benefits in the global trading system [6]. PTAs have grown beyond regional boundaries and enlarge in economic development and height. For example in 2007 about 380 PTAs were notified to GATT/WTO in-which 22 of the agreements drawn in developing nations and 200 operational in 2007, while less than $10 \%$ were customs unions [4]. [7] Confirmed to the explosion of PTAs increase and performance over its predecessor "WTO" and it's regarded as " Multiplied WTO" in various regions of the world with it adherence on a protective measure than WTO's policy. With an illustration of some measures taken as twosided agreement between developed and developing countries with stiff condition for intellectual property on developed to developing nations than WTO Trips agreement. The agreement might be obsolete, if not acted upon which holdup DOHA round of multilateral negotiation, as PTAs continues to explode [7].

\section{Trade Creation and Trade diversion.}

[8] posit that Doha round negotiation was below par to the prospect of multilateral liberalization and look desolate, while Preferential trade agreement continue to increase and enhance regional trade, despite multilateral is seen as superior to regionalism and welfare improvement. [8] Continued that regionalism may improve trade but has its effect on welfare and World trade system in general. However this can be illustrates through Trade Creation which is the formation of preferential trading agreement that lead to substitute of high cost domestic production by low-cost imports from other country [9]. Furthermore, if country a experience domestic high cost and import from Foreign country, which means such country demand shift from expensive secluded domestic production to cheaper import foreign production country, a shift from less efficient to a more efficient producer [10]. Depicting a clear beneficial and enhance efficiency with distribution of resource within each of the country, since lower cost and tariffs encourage more trade between member countries as result of economic integration leading to political influence, which can prompt trade liberalization, increase market, improved technology and employment opportunities within the countries involved and above all high welfare [11]

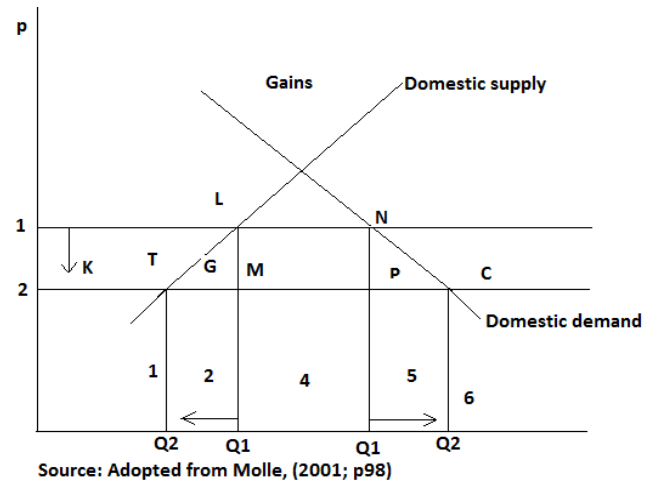

Fig 2.

\subsection{Trade creation.}

Trade creation result to efficiency gain and welfare, P1-P2 as tariff is eliminated, result of trade agreement price fall this enhanced the trading partners consumptions /welfare and fall in domestic production, high imports and trade creation with the advantage of making production more efficient which increased welfare for the country [10]. However, as the country involved in new imports, it does that at portion SC, and domestic 
consumer welfare area $\mathrm{K}, \mathrm{G}, \mathrm{P}$ while the country domestic producer faces losses area $\mathrm{T}$, on the other hand the country tariff revenue drop in area M, 4. result to a vague country welfare effect. Portion G, P from the graph as welfare net gain surpluses and better off for the country due to trade creation with imports loss tax area 4 . The country further increase welfare gain in area M, 4 and result to low-priced consumer purchase on import leading to trade creation [12]. [13] posits that trade creation entrance to cheaper supplies permit lower price which benefits consumers. On the other hand, lower prices leads to expansion of demand, rise in consumer surplus and result to net improved economic welfare. Therefore, when a country joins the trade bloc, the impact of demand and supply as a result of trade creation can either be inelastic or low the country's demand net gains and welfare.

\subsection{Trade Diversion.}

The formation of preferential trade agreement which result to the substitute of low-cost imports from non-member country with higher cost imports from member countries [14] posit that this occur as a result of regional bloc creation. As [15] noted that trade diversion "diverts imports from the latter to the former" that change is worldwide inefficient and result to unfavorable welfare effects on countries outside the union. And as trade creation effect dominate the union toward improving welfare; non-member countries are upset due to trade diversion occurrences. He stressed further, that PTAs could result to increased protection against non-member countries, which could lead to stumbling blocks of multilateral liberalization, and even if PTAs is primarily trade creating, the force to shield home industry could result to increase protection against non-member countries which could turn trade creation into trade diversion. However, the welfare effect of trade diversion is vague, though consumers improved, because of lower prices, but there are losses due to switch to less efficient producers and loss of tariff [11]. The challenges of trade diversion includes a distorted in country's sovereignty and not upholding trade policies due to deep economic integration and loss of consumers surplus.

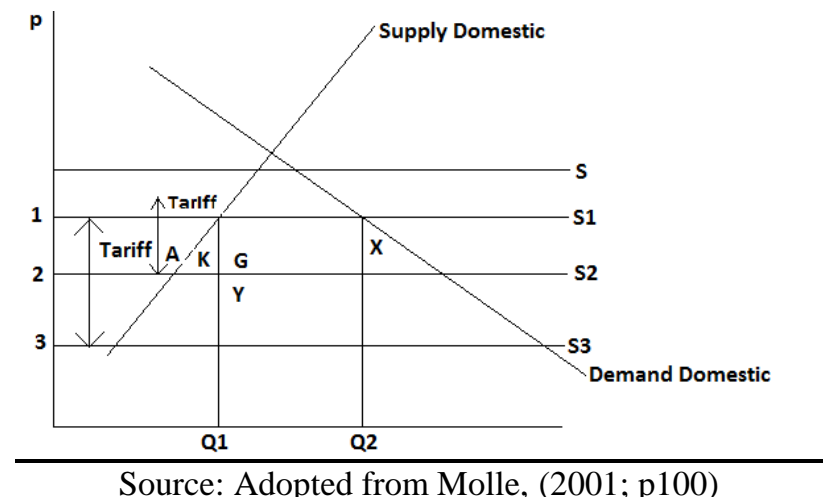

Fig 3.

Trade diversion price equilibrium and supply $1 \mathrm{Q} 1, \mathrm{Q} 2$ on country member elimination Price fall therefore, trade diversion derive consumption surplus to increase in area A,K,G \& X, while G, Y loss of government tariff, loss of jobs and $\mathrm{K}$, is reductions in production surplus, $\mathrm{K}, \mathrm{X}, \mathrm{Y}$ welfare increase, better off by trade diversion despite trade varies, a net loss or net gain depends on elasticity of demand [10] further, observed trade diversion is likely making less rational production which is a disadvantage to trade.

\section{Empirical Analysis of Trade Creation/Diversion.}

The vital issue is whether trade creation prevail over trade diversion as stated by [14] trade diversion remove internal trade barrier and may lead firms to strengthen their structures and adding-value activities to reflect regional market rather than national market. While on the other hand, [8] argued that trade creation redirect trade away from the most efficient global producers in the favor of regional partners which may prove welfare reducing and that, regionalism hinder multilateralism leading to awful equilibrium which much regional trade bloc uphold as high external trade barrier. Meanwhile, [16] stated that trade diversion enable countries devote more to exports and pay for imports, beside consumption switches to high cost country which could reduce efficiency and welfare gains such will be worse off rather than better off, for the fact that trade within the custom union is replace with countries outside the union is seen as loss. [17] argued that trade creation, stimulate and improve trade among member countries through increase technology which lead to high productivity efficiency, economics of scale, result to trade openness, gains in consumer and producers economic welfare. However, [18] viewed that both trade creation and trade diversion are indispensable activities for economic union of countries on trade, however they all provide better pricing due to elimination/reduce tariffs, though distinct, where trade creation provides real improvement of the price, trade diversion appears cheap at initial, when suppliers are diverted to the country inside the union. It then becomes cheaper owing to 
reduction of tariffs which could be expensive compare with the rest of the world. [19]the practical reason one need to hold is that trade creation and trade diversion both overlook some prospective gains from the custom union even on trade diversion, the added gains is the decrease of consumption alteration even while diverting. He put it further that regional free trade gains all the way through increase market size, both can accomplish productive efficiency, competitive gain and base on economies of scale.

However, since trade is not the same but varies in some many areas, regions countries and blocs, the impact plus effect equally varies. The argument is still subject to much debate, whether trade creation, outweigh trade diversion but it can unequivocally put that countries with comparative advantages but outside the bloc gains over those in the trading bloc who are disadvantage and it is detrimental to the country concern [10] posit that, trade creation outweigh trade diversion for the fact that a country substitutes high cost domestic production by low cost imports from other country, despite that, both trade increase trade and economic integration.

\section{Has PTAs Increase trade in the World?}

According to [4] PTAs improve access for export, credibility and confer punitive measures that is not in WTO; PTAs also offer profound market integration, enhance regional cooperation and global economic integration by complementing each other which serve as stepping-stone to wider global market over WTO. And most time integration eliminates barriers to trade; for example the European Union has a complete economic integration. Therefore, the strategy becomes a regional agreement for economic corporations and discriminatory eliminations of all barriers to trade, through economic and fiscal policies which aim at cost reduction for regions and improves trade between agreed countries [9].

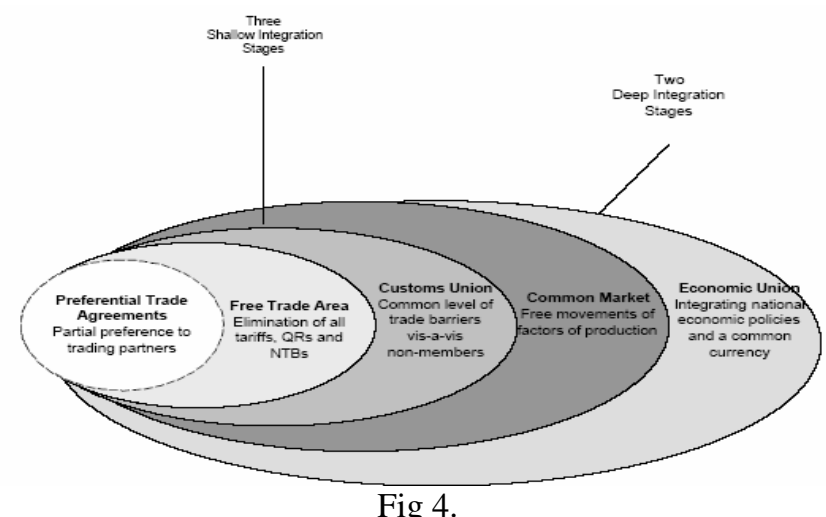

Source: Das (2001)

Fig 4.

However, countries desire to gain market access and trade opportunities increased much PTAs formation. More that WTOs, Doha Round unsuccessful has continual to increased PTAs and regional trade grouping in the World as observed by [20] large economies as US, EU and emerging economies as China, Indian faced wide choices of PTAs with diverse roles and increased multilateral functions, with U.S negotiating the western Hemisphere countries such as Mexico, Chile, and Singapore, Panama on the other side, exploring their PTAs roles [21].

Furthermore [21] posit the reasons for PTAs explode was owing to WTO executive supports on PTAs concession and failure of WTO on its difficult decisions, preserve constitution and consensus nature of decision making process which frustrate trade liberalizations and negotiations, which are among the challenges of WTO and why PTAs exploded.

The argument is whether PTAs increased trade [4] posits that PTAs took many form to advance its activities apart from enlarged trade by low tariff on import of associates countries, PTAs activities comes up recently to include "services trade and investment" which laid domestic and economic rules, political cooperation's, nation structure and international federalism. [22] advanced that that above reasons prompts many countries to opted PTAs as trade liberalization option, citing example, of [5] received 371 agreements, 193 in-forces was a sensitive agreement of new PTAs, merging high increased compare to 1980s, 1990s, which the burst was assumed to be in-line with the millennium age of DOHA round multilateral agreement.

However, to achieve efficiency and gain to the utmost in PTAs, the need for trade to include intellectual property protection, competition policy, partners' services provider exclusion and more regional formation. This will equally earn PTAs "deep integration" to market obligation, policy interdependence, advance trade and economic incorporation, which applies to international production system with structural control and low tariffs beyond, for this attest high increased trade volume by members' countries and high efficiency and welfare gains from PTAs countries over the years [5]. 


\section{Efficiencies and Welfare gains From Preferential Trade Agreement.}

However, efficiency and welfare are good factors of gaining trading agreement; it increases trade creation of nation economy and advances specialization of member's countries and improve income, through, easy imports from one another due to high tariff, while the efficiency gain by a shift from high cost domestic supply to low cost foreign supply result to comparative advantages [23]. However, large countries PTAs can increase the quantity of trade at high margin than smaller ones and reduces trade at high edge in fewer varieties from non-members. [2] explained that efficiency of member-countries is increase by improved bargaining power, country grow to be better off by achieving surplus return on trade and boost up their political influences. The unilateral exclusion of tariffs usually raise imports and increases domestic use and reducing domestic production, consumers gains prevail over losses of tariff revenue while, producer surplus leading to largely welfare gains [12]. A large economy can cause bigger net increase of demand and advance in real income, than a small country which encounters substantial trade diversion, [24]. However, country's welfare can be worse off as small member of large bloc than large member of small bloc and the welfare are more for low input demand countries and worse off as inputs of member country increases [25].

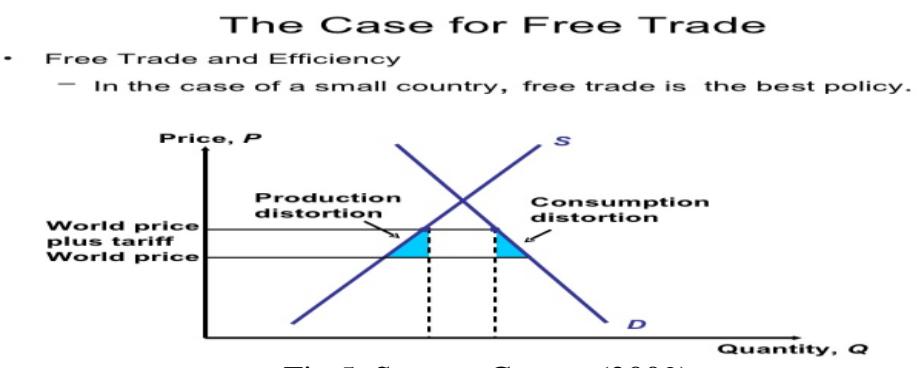

Fig 5. Source: Gopan, (2009).

Furthermore, [26] supports that multilateral trade hold series of preferential trade agreements involving the advanced countries over decades and enhanced welfare on the whole both to member countries and to the outside world. Observed by [2] PTAs reduces trade barrier which produce competitive demand and opportunity for technology movement result to higher productivity and welfare for member countries, while trade openness expand market size by attracting FDI, welfare and efficiency to both none and member-countries. However, this equally increases wealth of nations and regions by reduction in trade barriers, market increase and grow up especially large economies as EU and US [27].

However, developing economies benefit from economies of scale, cost reduction and deep multilateral trade liberalization, negotiation, integration and possibly regional bloc merger [2]. [1] Observed that apart from market access, PTAs is more used as engine for development and economic growth in many developing countries to promote growth, combat poverty and varied policy in area of investment and competition regulation via government procurement and regional integration. In their opinion the major reason for PTAs is the unity of small economies which make regional firms more efficient and competitive to bigger market and become efficient thus increases efficiency. Well, [11] viewed PTAs as wholly welfare enhancing agreement with slight trade diversion, citing NAFTA implementation of fairly low external tariffs and the overall trade within (imports from outside) the NAFTA region increase greatly and no priori confirmation of trade diversion, therefore NAFTA trade opportunity encouraged growth and trade relation which form trade building block toward larger multilateral integration and welfare. [26] Categorize the likelihood of trade creation/ diversion to ascertain, if the world economic welfare is increase or reduced due to preferential trade agreements, noting that the ratio of trade creation and diversion depend on the tariff of outside countries and the initial tariffs of member countries are equally high, since no trade without side countries. This enhances the welfare effect of PTAs, owing to low rates of member countries tariffs on imports from outside countries, thus trade increase welfare and efficiency [28].

\section{Evaluations of Preferential Trade Welfare, and Challenges.}

With the development of trade it is important to evaluate, several argument concerning the PTAs performance and welfare, their place in the world economy system as posits by [29] PTAs effect on welfare and gains could either be fixed or dynamic and that trade can achieve high production and efficiency owed to enhanced competition, reduce average production cost due to economies of scale in bigger market, high global investment, resulting from an increased competition, all these dynamics effects result to more welfare and gain. On the other hand, series of challenges and criticism are on support of non-performances of various PTAs in commiserating to its speedy explosion over time. [4] argued that the regular of all is the countries discrimination against non-member countries where tariff are lower or removed for trade partners countries, because of their interest in anchoring political cooperation, toward nation building and global federalism [14]. 
" They have a two-sided quality: they liberalize trade between

Members whilst, at the same time, discriminating against third parties.' [14].

The argument further looked at the DOHA round of WTO rule incompatibility [2], where the EU and US claim to lower subsidy over time, which favored only developed economies policies such as competition and government, procurement, where EU and US then get rid of subsidy to the detriments of distort trade. Further arguments advance by [22] that PTAs were just motivational formations and regional inclined citing the formation of EEC in 1958 metamorphosed into EU in 1992 and the developing nation's formation in 1960s, been strategies for imports substitution on achieving economies of scale and political prospects. Asserts that PTAs are more protectionists with lofty external barriers, while on the other hand, as non protectionist over non members and increases the value of compromise on members, while, making countries who entered PTAs becomes more protectionist to non-members when they become one, which mostly results to ineffective trade and not as good as market but more barriers. [27] argued that the discriminatory trade strategy of trade blocs is very high, citing example of FTA despite trade barrier is eliminated, each stays keen to its trade rule over nonmembers and in as much as the custom union liberalize intra-bloc trade, implement external tariff composition and trade barriers toward non-members and deep integration between members and non-members making PTAs welfare ambiguous and challenging. [26] argued that PTAs may possibly be unfavorable to the world welfare due to trade diverting outcome and unfair tariff tendency, because the formation of large trading blocs may prompt, as initial assumption that PTAs is required to be a welfare reducing. Argued further that U.S appear to have used the prospect toward the inside PTAs as means to stir up other major trading countries and blocs toward pursuing the multilateral option. [17] challenges PTAs of assuming adding-up rather than distorting trade efficiency, arguing that only member-country and custom unions tariff eliminated for a while, upholding high external tariff to non-members and therefore trade increase only member countries.

[1] PTAs is flattering bulky to manage, as agreement flourish countries turn into members of several different agreement especially developing nations, with examples of most Africa countries fitting into at least four diverse agreements and an average Latin American country belong to at least seven this can extend beyond different tariffs rules and custom procedures. Arguing that the gains and efficiency create by PTAs is lesser than those make from multilateral trade liberalization [2]. Therefore, [26] supports that PTAs most successful and strong agreement are those that involved highly developed and industrialized region, with example of Western Europe and North America, and preferential agreement among developing nations have in contrast, mostly not too effective but are only planned with the intention for import substitution.

The challenges further stretched out with government interference with policies on industrial locations within the PTAs territory, which result to failure due to ineffectiveness of the majority PTAs right from 1970s. None appear to contribute to economic growth, which result to the distorted number of PTAs because of strain debt predicament in 1980s; those who continue to exist are largely waning. As observed that:

'There is also an undoubted ' 'bandwagon', effect: a 'fear of being left out while the rest of the World swept into regionalism, either because this would be actually harmful to excluded countries or just because " if everyone is doing it, shouldn't we", [14].

In fact, the persist trade by PTAs distort trading model which concerned countries members and non-members countries and this have an effect on efficiencies, specialization and worse by most PTAs exist as non-reciprocal, subjective and incongruity with WTO rules. At the same time, PTAs can abolish trade barrier facing each other and with hold the non-member, example of free trade agreement and custom union [2].

However, importantly PTAs represent a movement in the direction of free trade, which is beneficial in terms of economic efficiency, argued by [26] that powerful trading blocs, countries found it relevant to adhere through their exploitative market power and trade. While, [5] posits that PTAs support countries to reduce the negative discrimination they experience for being non-PTAs trading countries and citing example of countries in South and Central America that drastically enhanced their market access situations between 2000 and 2007 , which basis was due to much PTAs sign at that period.

\section{Conclusion.}

The work stressed the basis of preferential trade agreement and how it enhanced market liberalization through border elimination and achieved global economic integration through the outburst of welfare and efficiency, especially for PTAs member countries [2].

Depending on the trade, trade creation/diversion are both essential in global trade. and even if trade is most efficient, it could not be real that a pace in that direction could necessity economic efficiency, whether a preferential trade agreement increase economic efficiency depend on the extent to which the agreement can cause trade diversion and trade creation [11]. [16] submits that trade increased economic efficiency and welfare of countries in the world, either without tariffs as in free trade countries such as NAFTA and based on agreed tariffs rates, customs union such as European Union or as a means to create large market as in developing countries trade expansion such as ASEAN, Mercosur [4]. 
Finally, trade varies, nevertheless trade increase welfare and efficiency, for the fact that high cost domestic is replace by low cost make trade creation more efficient and more welfare inclined over trade diversion which depicts outweigh over the later despite that, both trade increase welfare and integrates the economy [10].

\section{Bibliography.}

[1]. http://web.worldbank.org/WBSITE/EXTERNAL/TOPICS/TRADE/0,,contentMDK:22956131 pagePK:210058 piPK:210062 the SitePK:239071,00.html Preferential Trade Agreement Policies for Development, Maur, J. and Chaufour, J., 2011.

[2]. http://www.cuts-citee.org/pdf/monograph09-abc_of_preferential_trade_agreements.pdf ABC of PTAs: Frequently Asked Questions Kapil, K., 2009.

http://siteresources.worldbank.org/INTRANETTRADE/Resources/Contents.pd

[3]. Site Resource World Bank, Mohieldin, M., 2011.

[4]. The Political Economy of the World System the WTO and Beyond. $3^{\text {rd }}$ ed. New York: Oxford University Press. Kostecki, M. M., and Hoekman, M. B., 2009

http://www.wto.org/english/res e/publications e/wtr11 e.htm The WTO and PTAs: From Co-existence to Coherence, WTO, 2011.

[5]. http://www.wto.org/english/res e/booksp e/anrep e/wtr11-2d e.pd

[6]. Anatomy of Preferential Trade Agreements, WTO, 2011

http://www.voxeu.org/article/preferential-trade-agreements-and-wto. Preferential Trade Agreements and WTO (Graph) WTO Secretarial, 2011.

[7]. http://www.voxeu.org/article/preferential-trade-agreements-and-wto Preferential Trade Agreement, Teh, R. and Rocha, N., 2011. http://www.wto.org/english/res_e/publications_e/wtr11_forum_e/wtr11_12july11_bis_e.htm. PTAs Trade Creation and Trade Diversion, Nkuepo, J. H., 2011.

[8]. http://siteresources.worldbank.org/INTRANETTRADE/Resources/C6.pdf PTAs and Multilateral Liberalization, Fraud, C. and Baldwin, R., 2011.

[9]. http://www.slideshare.net/Pavithragl/preferential-trade-agreement Preferential Trade Agreement, Gopan, P.,2009. http://www.networkideas.org/feathm/may2004/survey_paper_rta.pdf

[10]. "Regional Trading Agreements and the Global Economy: An Asia-Pacific Perspective." Asian Development Bank, March 2004, Das, 2001.

[11]. The Economics of European Integration: Theory, Practice, Policy 4th ed. England Ash gate publishing Limited, Molle, W., 2001

[12]. http://proxy0.anglia.ac.uk:2068/ehost/pdfviewer/pdfviewer?vid=3\&sid=7520f9e9-09a9-4a84-92cebea68317c61e\%40sessionmgr14\&hid=12 Gains and Losses from Preferential Trade Agreement: Some Evidence from NAFTA. International trade journal, (e-journal) Vol: 21(2). Berdell, J. and Ghosha, A. 2007.

[13]. http://www.congreso.gob.pe/historico/cip/tlc/4_DOSSIER_TEMATICO/4_5/4_5_1/06.pdf Trade Creation and Trade Diversion in Canada- U.S Free Agreements., Canadian Journal of Economics, (e-journal) Vol: 34(3) (677-696). Clausing, A.K. 2001. http://www.economicshelp.org/dictionary/t/trade-creation.html Trade Agreement and trade areas, Geoff, R., 2012.

[14]. Global Shift: Mapping the Changing Contours of the World Economy. $6^{\text {th }}$ ed. London: SAGE Publication LTD. Dicken, P., 2011.

[15]. http://128.118.178.162/eps/it/papers/0308/0308014.pdf EU Preferential Trade Policies and Developing Countries, Panagariya, A., 2002.

[16]. International Economics, Theory, and Policy. $9^{\mathrm{TH}}$ ed. England Pearson Education Limited. Melitzer, J. M., Obstfeld, M. and Krugman, 2012.

[17]. http://books.google.co.uk/books?id=WG0zhlzEib8C\&pg=PA33\&lpg=PA33\&dq=what+the+gains+from+trade+diversion?\&source =bl\&ots=CTPenpaN0u\&sig=88uBbf2D-

qv3wCqMOUU4Vtmp1Xk\&hl=en\&sa=X\&ei=UqV5UYPHF8Sh0QWR8YC4Bw\&ved=0CHAQ6AEwCQ\#v=onepage\&q=what $\% 2$ 0the\%20gains\%20from\%20trade\%20diversion\%3F\&f=false Regional integration and Development, Winters, A. L., and Schiff, M., 2003.

[18]. http://maxwellsci.com/print/crjet/1-4.pdf The Dynamics of Trade Creation and Trade diversion effect under International Economic Integration, Current Research Journal of Economic Theory 1(1):1-4. (2042-485x), Dalimov, R. T., 2009.

[19]. http://www.kansascityfed.org/PUBLICAT/EconRev/EconRevArchive/1991/4q91.pdf\#page=7The Move toward Free Trade Zone, Krugman, P.1991.

[20]. http://www.academia.edu/1789633/The EU Preferential Trade Agreements Defining Priorities for a Debt-Ridden GrowthStarving_EU The EU Preferential Trade Agreement: Defining Priorities Debt-Ridden, Growth Starving EU Messerlin, P., 2012.

[21]. http://www.iit.adelaide.edu.au/docs/PTAWTO_Perth04.pdf Preferential Trade Agreement and The Role and Goals of the World Trade Organization, Stoler, L A., 2004.

[22]. http://www.stanford.edu/ assafzim/pta ad draft PTAs and Anti-Dumping Preliminary and incomplete, Zimring, A., 2012.

[23]. http://www.iadb.org/intal/intalcdi/PE/2012/09801a07.pdf. Economic Determinant of timing of Preferential Trade Formations and enlargements, Larch, M., Egger, P., and Berstrand, H., 2010.

[24]. https://digitalcollections.anu.edu.au/bitstream/1885/40368/3/di98-1.pdf

[25]. Source of Welfare gains and loss in forming Preferential Trade, Yang, Y., 1998.

[26]. http://site.ebrary.com/lib/anglia/docDetail.action?docID=10506414 Preferential Trade Agreement Policies for Development, A hand book (P69) Herndon. U.S.A., Maur, C.J. and Chaufour, J., 2011.

[27]. http://www.fordschool.umich.edu/rsie/workingpapers/PPP1-25/ppp4.pdf

[28]. Multilateral Trade Negotiation and PTAs, Stern, M. R., and Deardorff, V. A., 1994.

[29]. http://www.ecdpm.org/Web ECDPM/Web/Content/Download.nsf/0/7063A1D7D8686243C12574980049FDAD/\$FILE/Trade\%20 Blocs.pdf 'Trade blocs," in R. Jones.,Routledge Encyclopedia of international Political economy, Rutledge, Fourth Coming, Bilal, S., 2001

[30]. Economic Development, Growth, and Welfare. $1^{\text {st }}$ ed. London: The Macmillan Press LTD, Smith, C., 1994.

[31]. http://www.etsg.org/ETSG2009/papers/muhammad.pdf Impact of Regional Trade Agreement: Trade Creation and Trade Diversion in Western Hemisphere, Aycil, Y.and Kabeer, M., 2009. 